numerous instances the larger blossoms of each family are so exclusively adapted to insect fertilisation that they cannot fertilise themselves; while among the smaller blossoms alternative devices for self-fertilisation commonly come into play after the flower has been open for some time, if it has not first been cross-fertilised. Structural considerations show us that in most of such instances the larger and purely entomophilous fiowers are the more primitive, while the smaller and occasionally self-fertilising flowers are derivative and degraded, having usually lost some oi their parts. Hence, in tracing the progressive law of colouration in the families generally, it is necessary, for the most part, to consider only the larger and more typical species, setting aside most of the smaller as products of degeneration.

GRANT ALLEN

(To be continued.)

\section{NOTE ON THE HISTORY OF OPTICAI. GLASS}

M. FEIL has been good enough to send us the followLouis Guinaud :-

Pierre Louis Guinaud was born at Bresset in the canton of Neuchatel, Switzerland, in 1742 , and died in 1821 . $\mathrm{He}$ was nearly sixteen years old when Herschel visited Switzerland, and with Alschneider made some telescopic experiments on the Tête Doran. Young Guinaud, who acted as shepherd by day, and at night worked in a bell manufactory, occasionally was present at the meetings of these gentlemen, and attracted their attention and good will by many services.

His curiosity was greatly aroused, and after having been allowed to look through the telescope, he asked Herschel to dismount the instrument, as he wished to see how it was made; doubtless struck by his wonderful intelligence, the illustrious savant showed him the details of its construction.

The following year this gentlemen returned to Switzerland with Dollond and Faraday. Young Guinaud must have utilised the intervening time, for he showed Herschel, whom he was able to call his benefactor, a telescope which he himself had made, the mirror being of bellmetal. Imperfect as such an instrument must necessarily have been, it proved his strength of will and aptitude for optics.

$\mathrm{He}$ had pondered over the subject and asked why large object-glasses had not been made? There are no glasses in existence suitable to make them," was the answer. "Make some, if you can," said Alschneider. "I will make some," replied Guinaud. But he required money. He set to work, and, being a clever workman, soon invented the bells of repeaters, which proved very lucrative. All that he earned was devoted to the establishment of small glass-works. What power of research and perseverance must this man have possessed, who, without any other resource but his genius, started the most difficult branch of glass making, in order to solve a problem which was incomprehensible to Faraday and Dartigères? For ten years everything was devoted to his work. One casting failed, and was thrown into the torrent which flowed at the foot of the mountain on which he had built his factory. He had chosen the highest and most inaccessible point, having to defend himself against the ignorance of his neighbours, who treated him as a sorcerer, and several times his place was sacked. He utilised a stream of water in order to work a hydraulic wheel for the pulverisation of these materials, the sawing and working up of these blocks of glass. Nevertheless, the attention of the scientific world was already drawn to the modest worker. Alschneider had become his friend. About 1806 he sold a disc of six inches to Lerebours, and at nearly the same time he sent an eight-inch to Dollond; the problem was solved. He furnished Panchoni and Lerebour with discs of twelve inches. The twelve-inch object-glass belonging to Causham was bought for 2,500 francs by Faraday. Alschneider begged him to go to Munich and associate himself with Fraunhofer. But at the end of about three years the desire to see his mountains again took possession of him, and he renounced all his advantages and returned to continue his work alone. France offered him a pension from the state, a secret patent for fifteen years, and a factory fully established; but he refused to accede to the offers of the minister of Vitellius, and died in I821. After his death his son, Henri Guinaud, who had always lived in France from the age of fifteen, was put into communication by Lerebours with MM. Bon. temps and Thibaudau, proprietors of the glass-works at Choisy-le-Roi. He had seen several experiments during the journeys he had taken with his father. He taught these gentlemen all he knew of his father's processes, but, obliged by penury to quit them, he returned to Paris, and founded, with his son-in-law, M. Feil, my father, a small glass-work in the Rue Mouffetard. This was in I 832 .

In 1838 Henri Guinaud received the gold medal of the Academy of Sciences, in 1839 the great prize in astronomy, one part of which was given to M. Bontemps. He presented to the Academy of Sciences a disc of eighteen inches diameter. I succeeded him in 1848 , and was his pupil for six years. He died in 1851 , carrying with him the regrets of all scientific men, who, like the Aragos, Gambays, Thénards, and Dumas, had appreciated his cleverness and his talents, and who were his friends and protectors.

\section{NOTES}

THE French Association for the Advancement of Science meets this year at $\mathrm{La}$ Rochelle, on the $24^{\text {th }}$ in t., for its eleventh session. M. Janssen is the President elect. Tuo lectures are to be delivered, one by $M$. Bouquet de la Grye, on the deep water harbour of La Rochelle; the other by $M$. Hospitalier, on the electric light. There will be excursions to the places where oysters and mussels are cultivated. Deep-sea dredging will take place on board the Ardisnade, under the direction of Prof. Giard, of Lille. A reduction of $5^{\circ}$ per cent. will be granted on the French railways to the members of the Association. Among foreign savants expected to attend the meeting are Prof. Hennessy of Dublin, Prof. van Beneden of Louvain, with several other Belgians, Prof. Baehr of Delft, and two other Dutch savants, Signor Denza, of Moncalieri Observatory, and two other Italians, Chevalier di Silva, Royal Architect, from Lisbon, Prof. Vittanova of Madrid, and M. de Loriol of Geneva. Among the subjects of papers we note briefly the following :-The Channel Tunnel ; A merican glaciers; transformation of work into heat, and reciprocally; marbles of Italian quarries; employment of portable railways in the war in Tunis; geodetic works in Italy; the salubrity of collective dwellings; aërodynamics and solar heat; the topoveloce; a new gyroscopic box; a geometrical generation of Fraunhofer's lines; theory of vowels ; isotherms on mountains ; registering capillary electrometer; new pressureanemograph; best coloured signals for beacons, \&c. ; : ulphurous acid in Lille atmosphere; aërial navigation; photometry for light of different colours; severe winters; distribution of the atmosphere in the two hemispheres; ammoniacal fermentation; determination of salicylic acid in alimentary substances; action of oxalic acid on polyatomic alcohols ; formation of alkaloids in protoplasm; bases of the quinoleic series; electro-therapeutic treatment of vomiting; double consciousness ; teas of commerce ; anæsthesia in croup; anthropology of evolution; the cause of goitre; intestinal parasites of oysters; thermal waters in the 